\title{
JÄNNITTEISYYS OPETTAJAN JA OPPIJAN VUOROVAIKUTUSSUHTEESSA
}

\author{
Maija Gerlander, FT \\ Helingin yliopisto
}

Emma Kostiainen, FT

Opettajankoulutuslaitos, Jyväskylän yliopisto

\section{TIIVISTELMÄ}

Artikkelissa tarkastellaan opettajan ja oppilaan välisen vuorovaikutussuhteen luonnetta ja dynamiikkaa relationaalisen dialektiikan näkökulmasta. Opettajan ja oppijan vuorovaikutussuhde määritellään ensinnäkin kaksisuuntaiseksi viestintäsuhteeksi, jossa kuvastuvat ja rakentuvat suhteen ulottuvuudet sekä opettajan ja oppijoiden identiteetit. Vuorovaikutussuhde nähdään ensisijaisesti viestinnässä syntyvänä ilmiönä, ei etukäteen annettuna suhdekategoriana. Viestintää tarkastellaan konstitutiivisena prosessina, jossa henkilöt ja suhteet, kuten opettaja ja oppija, eivät ole analyyttisesti erotettavissa viestinnästä erillisinä entiteetteinä, vaan ne ovat vuorovaikutuskäytänteissä syntyviä, ylläpidettäviä ja muuttuvia vuorovaikutusidentiteettejä, positioita. Toiseksi opettajan ja oppijan vuorovaikutussuhde ymmärretään lähtökohdiltaan asymmetrisenä ja jännitteisenä eli vastakkaisia elementtejä sisältävänä dialektisena suhteena. Asymmetrisyys nousee osapuolten erilaisista tehtävistä ja siten erilaisesta näkökulmasta suhteeseen. Artikkelissa tarkastellaan riippuvaisuuden ja autonomisuuden, välittämisen ja instrumentaalisuuden, arvioimisen ja hyväksymisen sekä ilmaisemisen ja suojaamisen välisiä jännitteitä opettaja-oppijasuhteessa sekä pohditaan dialogia vuorovaikutuksen jännitteisyyden näkökulmasta. Asiasanat: asymmetrinen viestintäsubde, dialogi, opettaja-oppijavuorovaikutussubde, relationaalinen dialektiikkea, vnorovaikutuksen jännitteisyys

\section{JoHDANTO}

Opettajan ja oppijan vuorovaikutussuhde on yksi tyypillisimmistä institutionaalisista vuorovaikutussuhteista. Meillä jokaisella on siitä kokemuksia, jotka ovat voineet myönteisyydellään tai kielteisyydellään vahvastikin vaikuttaa siihen, mitä ja miten olemme opiskelleet, mitä ajattelemme itsestämme oppijoina tai millaisiin työtehtäviin olemme hakeutuneet. Tässä artikkelissa tarkastellaan teoreettis-käsitteellisistä näkökulmista opettajan ja oppijan välisen vuorovaikutussuhteen luonnetta ja dynamiikkaa.

Opettaja-oppijasuhteen luonnetta tarkastellaan relationaalisten jännitteiden kautta, jotka ovat relationaalisen dialektiikan keskeisiä käsitteitä (ks. Baxter \& Montgomery 1996; Rawlins 2000). Viestintätieteissä relationaalinen 
dialektiilkka on löyhä teoreettinen viitekehys tai näkökulma, jonka tarkastelun kohteena ovat ihmisten väliset suhteet ja niiden dynamiikka. Relationaalisten jännitteiden nähdään kuuluvan opettaja-oppijasuhteen perusolemukseen. Relationaalista dialektiikkaa on käytetty ensisijaisesti läheisten viestintäsuhteiden, kuten pari- ja ystäryyssuhteiden tutkimiseen (ks. Baxter 2004; Rawlins 1998). Professionaalisiin tai institutionaalisiin viestintäsuhteisiin sitä on sovellettu vain muutamissa tutkimuksissa, kuten opettajan ja oppijan (Rawlins 2000), ohjaajan ja jatko-opiskelijaohjattavan (Poutiainen \& Gerlander 2005) sekä lääkärin ja potilaan välisen suhteen tarkastelussa (Gerlander 2003).

Artikkelin alussa luonnehditaan tiiviisti aikaisempaa opettajan ja oppijan vuorovaikutussuhteen tutkimusta, minkä jälkeen määritellään opettajan ja oppijan välisen vuorovaikutuksen käsitettä. Vuorovaikutussuhteen relationaalisia jännitteitä käsittelevän luvun alussa esitellään relationaalisen dialektiikan teoreettinen viitekehys sekä määritellään sen ydinkäsite, relationaalinen jännite. Artikkelin lopussa pohditaan, mitä jännitteisyyden näkökulma tarjoaa opettajaoppijasuhteen tarkastelulle, erityisesti käsitykselle dialogista, sekä mitä aiheita sen pohjalta voidaan nostaa tutkimuksen kohteeksi.

\section{留 OPETTAJA-OPPIJAVUOROVAIKUTUSSUHTEEN}

\section{NÄKYMÄTTÖMYYS OPETUSVIESTINNÄN TUTKIMUKSESSA}

Opetusviestintä (instructional communication) on yksi puheviestintätieteen perinteisiä tutkimusalueita. Opetusviestinnän tutkimuskohde on laaja: siihen sisältyy viestintä kaikenlaisissa opetuskonteksteissa tai -ympäristöissä ja millä tahansa alalla tai kouluasteella (ks. esim. McCroskey, Richmond \& McCroskey 2002; Staton 1989).

Opetusviestinnän tutkimuksissa on perinteisesti tarkasteltu opettajan viestintää, kuten opettajien välittömyyttä ja viestintä- tai sosiokommunikatiivista tyyliä (ks. esim. McCaleb 1987; McCroskey, Richmond \& McCroskey 2002; Sallinen-Kuparinen 1987; 1992). Yksi keskeisimmistä opetusviestinnän tutkimuksen tavoitteista on ollut selvittää opettajan viestinnän ja oppimisen välisiä yhteyksiä (ks. esim. McCroskey, Sallinen, Frayer, Richmond \& Barraclough 1996; Witt \& Wheeless 2001). Lisäksi on tutkittu opettajan kokemia viestintähuolia (ks. esim. Seppälä 1995) tai opettajan vallankäyttöä (ks. esim. BoothButterfield 1992; Richmond \& McCroskey 1992) sekä opettajan viestintätaitoja tai -osaamista (ks. esim. Bruschke \& Gartner 1991; Feezel 1987). Oppilaiden viestinnässä keskeinen tutkimuskohde on ollut viestintäarkuus tai esiintymisjännitys (ks. esim. Burk 2001). Lisäksi on tutkittu oppilaiden viestintähalukkuutta ja viestintätaitoja (ks. esim. Almeida 2004).

Tarkastelun kohteena tutkimuksissa on siis ollut joko opettajan tai oppijoiden viestintäkäyttäytyminen. Kuitenkaan opettajan ja oppijan pitäminen erillisinä viestintäosapuolina ei riitä kuvaamaan opettajan ja oppijoiden välistä 
suhdetta. Niitä tutkimalla ei pystytä selvittämään esimerkiksi sitä, miten opettaja-oppijasuhde rakentuu, miten sitä ylläpidetään tai millaiset asiat horjuttavat sitä. Opettajan ja oppijan viestintää erillisinä tarkastelemalla ei myöskään voida tutkia sitä, miten opettajan ja oppijan vuorovaikutussuhde ja sen piirteet vaikuttavat oppimiseen (Nussbaum \& Friedrich 2005, 578). Opettaminen, opiskelu ja oppiminen kietoutuvat opetustilanteen vuorovaikutussuhteisiin, niin opettajan ja oppijoiden välisiin kuin oppijoiden keskinäisiin. Esimerkiksi Rawlinsille $(2000,5)$ opettaminen on olennaisesti suhteisiin sisältyvää, "inherently relational". Suhdenäkökulma on tullut esille viimeaikaisessa opetusviestinnän tutkimuksessa, jossa on käsitelty esimerkiksi opettajan viestintätaitojen lisäksi opettajan vuorovaikutusosaamista eli opettaja-oppilassuhteen rakentumista ja ylläpitämistä (ks. esim. Frymier \& Houser 2000; Martin, Myers \& Mottet 1999). Suhdenäkökulman esille nostaminen edellyttää kuitenkin sitä, että opetusviestinnän tutkimuksissa vuorovaikutussuhde pystytään käsitteellistämään selkeämmin, minkä jälkeen sitä voidaan myös tarkastella jäsentyneemmin.

Suhteen merkitys ja suhdenäkökulma opettamisessa on ollut esillä myös kasvatustieteellisissä tutkimuksissa ja opettajankoulutuksessa. Esimerkiksi Harjunen (2002) tarkastelee opettajan pedagogista auktoriteettia käsittelevässä tutkimuksessaan opettamista nimenomaan opettaja-oppilassuhteen kannalta. Hänen $(2002,464)$ mukaansa opettaminen ja opettajuus ovat pitkälti suhdetoimintaa, vaikka suhdenäkökulmasta ei saateta liiemmin puhua teknisempien, aineen opettamiseen liittyvien asioiden viedessä ajan. Kansanen (1999) puolestaan asettaa opettajan ja oppijan vuorovaikutussuhteen yhdeksi opettamis-opiskelu-oppimisprosessin peruselementiksi. Opettajankoulutuksessa vuorovaikutuksen merkitys on nähty tärkeänä oppimisen ja opettajana kehittymisen alueena (ks. Rasku-Puttonen \& Rönkä 2004). Harjunen (2002, 464) kuitenkin toteaa, että opettajankoulutuksessa käsitellään vuorovaikutustilanteita, mutta ei puhuta suhteista. Yhtenä syynä tarkastelun vähyyteen on todennäköisesti suhdetta koskevien jäsennysten niukkuus. Näyttää siltä, että sekä puheviestintätieteellisessä että kasvatustieteellisessä tutkimuksessa opettajan ja oppijan suhteen tarkastelun tarpeellisuus on tunnistettu, vaikka aiheen tutkimus on vielä vähäistä.

\section{Mitä TARKOITETAAN OPETTAJAN JA OPPIJAN VUOROVAIKUTUSSUHTEELLA?}

Vaikka opettajan ja oppijan välinen vuorovaikutus on paljon käytetty käsite sekä puheviestinnän että kasvatustieteen tutkimuksissa, sitä ei useinkaan tarkemmin käsitteellisesti määritellä. Sillä voidaan tarkoittaa laajasti oppijan ja opettajan välisiä, toisiinsa vaikuttavia tekoja tai toimintoja tai spesifisti kasvokkaista, kahdenkeskistä vuorovaikutusta. Tässä artikkelissa opettajan ja op- 
pijan välinen vuorovaikutussuhde ymmärretään ontologisesti viestinnälliseksi ilmiöksi: se on ensisijaisesti viestintäprosessi (ks. Penman 2000, 1), jossa luodaan ja jaetaan merkityksiä ja jossa viestinnän sisältö on aina jossakin suhdeympäristössä ja siten tarkasteltavissa relationaalisesta näkökulmasta.

Opettajan ja oppijan vuorovaikutussuhde ymmärretään ensinnäkin kaksisunntaiseksi viestintäsubteeksi, jossa kuvastuvat ja rakentuvat suhteen ulottuvuudet sekä opettajan ja oppijoiden identiteetit. Viestintätieteessä vuorovaikutus määritellään usein viestintäprosessin piirteenä tai ominaisuutena, kun halutaan korostaan viestinnän kaksisuuntaisuutta sekä viestintäosapuolten - kuten opettajan ja oppijan - toimintojen tai kognitioiden samanaikaisuutta. Viestintätekojen sisällöllinen liittyminen toisïnsa (ts. merkitysten tulkinta ja huomioonottaminen) tekee viestintäprosessista vuorovaikutusta. Tällöin ei voi olla vuorovaikutusta ilman sisältöä tai arvoja. Näin ollen opettaja-oppijasuhde nähdään ensisijaisesti viestinnällisenä, viestinnässä syntyvänä ilmiönä, ei etukäteen annettuna suhdekategoriana. Artikkelissa käytetään käsitteitä opettaja-oppijasuhde sekä opettajan ja oppijan välinen vuorovaikutussuhde, jotka molemmat pohjautuvat viestinnälliseen näkemykseen suhteesta. Vuorovaikutussuhdetta käytetään silloin, kun halutaan korostaa suhteen viestinnällistä luonnetta, niitä viestintäprosesseja ja -käytänteitä, jossa suhde syntyy.

Tämän näkemyksen lähtökohtana on viestinnän ymmärtäminen myös konstitutiivisena prosessina (ks. Deetz 1994; Leeds-Hurwitz 1995; Sigman 1998). Siksi tarkasti ottaen ei voida puhua viestinnästä suhteissa, joka antaa ymmärtää suhteen ja viestinnän erillisiksi ilmiöiksi ja että viestintä on vain yksi muuttuja monien muiden joukossa, vaan suhteista viestinnässä (Baxter 2004). Tästä seuraa, että henkilöt ja suhteet, kuten opettaja ja oppija, eivät ole analyyttisesti erotettavissa viestinnästä erillisinä entiteetteinä, vaan ne ovat vuorovaikutus käytänteissä syntyviä, ylläpidettäviä ja muuttuvia vuorovaikutusidentiteettejä, positioita. Opettajuutta ja oppijuutta siis luodaan ja ylläpidetään ja niitä voidaan myös uhata ja murentaa vuorovaikutuksessa.

Toiseksi opettajan ja oppijan vuorovaikutussuhde ymmärretään lähtökohdiltaan asymmetrisenä ja jännitteisenä eli vastakkaisia elementtejä sisältävänä dialektisena suhteena. Asymmetrisyys nousee osapuolten erilaisista tehtävistä ja niihin liittyen erilaisista suhteeseen liittyvistä oikeuksista ja velvollisuuksista ja siten erilaisesta näkökulmasta suhteeseen. On tyypillistä ajatella, että opettajan tehtävänä on opettaa eli suunnitella, organisoida ja ohjata oppimistilanteen toimintaa ja työskentelyä, huolehtia ilmapiiristä ja oppimista edistävästä vuorovaikutuksesta sekä motivoida ja antaa palautetta (ks. Harjunen 2002, 61; Kansanen 1999). Oppijan tehtävä on puolestaan opiskella ja pyrkiä oppimaan mahdollisimman hyvin. Suhdetta voidaan ensisijaisesti pitää tehtäväkeskeisenä, mutta siihen liittyy olennaisesti myös henkilökohtaisille suhteille ominaista välittämistä. 
Relationaalisen viestinnän näkökulma ottaa huomioon sen, että viestillä on samanaikaisesti sekä sisältöulottuvuus että suhdeulottuvuus (ks. esim. Griffin 2003; Trenholm \& Jensen 1992). Viestin sisältöulottuvuudella tarkoitetaan kaikkea sitä, mitä vuorovaikutusosapuolet konkreettisesti sanovat toisilleen. Viestin relationaalinen ulottuvuus puolestaan antaa vihjeitä siitä, miten viestin sisältö tulisi tulkita (Watzlawick, Bavelas \& Jackson 1967, 52). Se antaa vuorovaikutusosapuolille tietoa siitä, oliko viesti tarkoitettu esimerkiksi vähätteleväksi, vilpittömäksi ystävyyden osoitukseksi, sarkastiseksi huomautukseksi vai kenties vitsiksi. Viestin suhdemerkitykset välittyvät olennaisesti nonverbaalisen merkkijärjestelmän kautta (ks. Trenholm \& Jensen 1992, 367). Viestin sisältö toteutuu aina jossakin suhteessa, joka rakentuu viestintäprosessin edetessä. Aina kun sanomme jotain, luomme samanaikaisesti toistemme välisen suhteen ja määrittelemme sekä omaa että toisen vuorovaikutusidentiteettiä (ks. Tracy 2000). Näin viestin relationaalinen ulottuvuus antaa vuorovaikutusosapuolille tietoa siitä, mitä he toisistaan ajattelevat (ks. Trenholm \& Jensen 1992, 236).

Opetuksen kannalta relationaalinen ulottuvuus merkitsee sitä, että ei ole olemassa pelkkää sisältöä: koska sisältö toteutuu aina suhdeympäristössä, suhdeulottuvuus vaikuttaa myös sisällölle annettavaan merkitykseen. Tällöin se merkitsee myös sitä, että viestintä ei ole vain viihtyvyystekijä tai kognitiivista oppimista tukeva elementti, vaan myös oppimisen paikka tai tila. Tiedosta ja tietämisestä tulee siis ensisijaisesti sosiaalisen toiminnan, vuorovaikutuksen tulosta, ei yksilön pään sisäistä prosessointia. Opetus- ja ohjaustilanteiden vuorovaikutuksen merkitys kasvaa, sillä vuorovaikutuksen laatu kuvastaa osaltaan oppimisen laatua. Relationaalisen näkökulman soveltamisen seurauksena opetuksessa ja ohjauksessa korostuvat sosiaaliset ja sosioemotionaaliset prosessit (ks. myös Kumpulainen \& Wray 2004, 12). Tällöin esimerkiksi tunteiden merkitys oppimisessa korostuu, koska tunteet - niiden ilmaiseminen, tulkinta ja niistä neuvotteleminen vuorovaikutussuhteissa - asettuvat myös oppimista konstituoiviksi tekijöiksi (ks. Vehviläinen 2004).

\section{RELATIONAALISET JÄNNITTEET OPETTAJAN JA OPPIJAN VUOROVAIKUTUSSUHTEESSA}

Relationaaliset jännitteet ovat relationaalisen dialektiikan teorian keskeinen käsite. Teorian ydinajatus on, että suhteet syntyvät, niitä ylläpidetään ja ne muuttuvat viestinnässä ilmenevien ja siinä syntyvien vastakkaisten voimien dynaamisessa vuorovaikutuksessa. Vastakkaisten voimien välinen jatkuva dialogi tekee suhteista dynaamisia, alati liikkeessä olevia entiteettejä (ks. Baxter 2004; Baxter \& Montgomery 1996). Suhteet eivät näin ollen ole stabileeja, eikä niiden myöskään ajatella kehittyvän kohti tiettyä päämäärää tai tiettyyn suuntaan.

Relationaaliset jännitteet ovat suhteeseen olennaisesti kuuluvia, vastakkai- 
sia verbaalis-ideologisia voimia tai diskursseja, joissa on kysymys kilpailevista näkökulmista, orientaatioista, arvoista ja tehtävistä (ks. Baxter 2004, 8; Baxter \& Montgomery 1996). Ne eivät ole yksilöiden kognitiivisia dilemmoja, vaan suhteen olennaisia osia, joista ei voi päästä eroon kadottamatta koko suhdetta. Relationaaliset jännitteet eivät siis ole ratkaistavia ongelmia tai konflikteja, vaikka ne voivatkin vaikuttaa ongelmien ja konfliktien syntymiseen ja ilmenemiseen. Näin ollen opettaja-oppijasuhteen asymmetrisyys ilmenee vuorovaikutussuhteen jännitteissä ja osaltaan asymmetrisyys myös ruokkii tietynlaisten jännitteiden syntymistä.

Koska ristiriitaisuudet ja jännitteet nähdään luonnollisena viestinnän tilana ja viestintäkäyttäytymisen lähteenä (Mifsud \& Johnson 2000, 93), relationaalista dialektiikkaa onkin luonnehdittu ontologiseksi dialektiikaksi (erotuksena totuutta ja tietämistä tarkastelevasta epistemologisesta dialektiikasta). Relationaalisen dialektiikan kehittäjät Leslie Baxter ja Margaret Montgomery nimittävät teoriaansa myös dialogisesti orientoituneeksi dialektiikaksi, koska se perustuu vahvasti Bahtinin dialogifilosofiaan, erityisesti ajatukseen vastakkaisten, toisiaan vetävien (centripetal) ja erottavien (centrifugal) voimien jatkuvasta vuorovaikutuksesta. Sosiaalinen todellisuus on Bahtinille $(1981,272)$ jännitteiden kyllästämä, ristiriitaisten voimien vuorovaikutuksesta muodostuva kokonaisuus.

Olennaista on ymmärtää jännitteiden samanaikaisuus. Esimerkiksi läheisyys ja etäisyys nähdään samanaikaisesti läsnä oleviksi, toisiinsa kietoutuviksi kokonaisuuksiksi, jotka toisensa kieltäessään ovat samalla riippuvaisia toisistaan. Tämä merkitsee sitä, että vuorovaikutussuhteessa on samanaikaisesti sekä avoimuutta ja suojaamista, odotuksenmukaisuutta ja yllätyksellisyyttä, läheisyyttä ja etäisyyttä jne. Esimerkiksi oppija tarvitsee oman autonomisuutensa ilmentämiseen ja rakentamiseen vuorovaikutussuhteita opettajaan ja toisiin oppijoihin.

Aikaisemmissa tutkimuksissa henkilökohtaisten suhteiden perusjännitteiksi ovat muotoutuneet integraation ja separaation, stabiliuden ja muutoksen sekä ilmaisemisen/avoimuuden ja yksityisyyden väliset jännitteet (ks. Baxter 2004). Niitä pidetään jo vakiintuneina läheisten vuorovaikutussuhteiden perusjännitteinä. Kuitenkin on huomattava, että jännitteitä kuvaavat termit eivät ole vakiintuneita. Samaa tarkoittava jännite voidaan eri tutkimuksissa nimetä eri tavoin. Osa nimikkeistä on synonyymeja, mutta osa kuvastaa jännitteen tilannekohtaisuutta. Esimerkiksi integraation ja separaation välinen jännite on voitu nimetä samanlaisuuden ja erilaisuuden ja "minä" ja "me" -identiteetin väliseksi jännitteeksi (Baxter 2004, 9) tai sitä on kuvattu autonomisuuden ja rïppuvaisuuden väliseksi jännitteeksi (ks. Gerlander 2003).

Rawlins (2000) on tarkastellut opettaja-oppijasuhdetta pedagogisena ystävyyssuhteena ja nimennyt opettajan näkökulmasta katsottuna seuraavat neljä jännitettä: 
1) riippuvaisuuden ja riippumattomuuden (autonomisuus) välinen jännite,

2) välittämisen ja instrumentaalisuuden välinen jännite,

3) arvioimisen ja hyväksymisen välinen jännite sekä

4) ilmaisemisen ja suojaamisen välinen jännite.

Osittain yhdenmukaisia Rawlinsin jännitteiden kanssa ovat Poutiaisen ja Gerlanderin (2005) nimeämät suomalaisten jatko-opiskelijoiden ja ohjaajien vuorovaikutussuhteessa ilmenevät jännitteet: autonomisuus - riippuvaisuus, asiakeskeisyys - henkilökohtaisuus, asymmetrisyys - symmetrisyys sekä arviointi - hyväksyminen. Rawlinsin (2000) kuvailemat jännitteet perustuvat hänen omien opiskelijoidensa antamiin vastauksiin. Tarkemmin hän ei artikkelissaan aineistoaan määrittele. Poutiaisen ja Gerlanderin (2005) tutkimus pohjautuu kolmen jatko-opiskelijan ja kolmen ohjaajan haastatteluihin (he eivät olleet ohjaussuhteessa toisiinsa). Haastateltavat edustivat humanistisia ja taidealoja. Lisäksi tutkimuksessa analysoitiin lehdistössä käytyä ohjausta koskenutta julkista keskustelua. Molempien tutkimusten jännitteet liittyvät erityisesti ohjaussuhteen tarkasteluun, mutta niitä voidaan soveltaa myös yleisemmin opettaja-oppijasuhteisiin. Seuraavaksi avaamme riippuvaisuuden ja autonomisuuden, välittämisen ja instrumentaalisuuden, arvioimisen ja hyväksymisen sekä ilmaisemisen ja suojaamisen välisiä jännitteitä ja pohdimme niiden ilmenemistä opettaja-oppijasuhteessa erityisesti opettajan näkökulmasta katsottuna. Painotamme tarkastelussa kahta ensimmäistä jännitettä.

Jännite rïppuvaisuuden ja autonomisunden välillä kuvastaa esimerkiksi oppijoiden samanaikaista tarvetta itsenäisyyteen ja riippuvaisuuteen, kuten opettajan huomioon, tukeen ja ohjaukseen. Opettajan näkökulmasta keskeinen kysymys on, miten tukea oppijan riippumattomuutta ja kehittymistä itseohjautuvammaksi oppijaksi, mutta toisaalta olla riittävästi tukemassa ja ohjaamassa. Kun ohjaussuhteessa pohditaan, onko se liiallista "paapomista" tai hylkäämistä, käsitellään juuri riippuvaisuuden ja autonomisuuden välistä jännitettä.

Esimerkiksi Poutiaisen ja Gerlanderin (2005) tutkimuksessa riippuvaisuuden ja riippumattomuuden välinen jännite ilmeni jatko-opiskelijoiden halussa olla vapaita, säilyttää ja ylläpitää vapaus sekä tehdä, mitä haluaa. Jos opiskelijalle annetaan liikaa vapautta, seurauksena voi olla kokemus välinpitämättömyydestä ja heitteille jätetyksi tulemisesta. Toisaalta oppija voi pyrkiä liialliseen itsenäisyyteen ja autonomiaan esimerkiksi silloin, kun hän ei pysty näkemään opettajan kommenttien ja neuvojen arvoa. Ohjaussuhteessa liian vähäinen vapaus voi puolestaan tarkoittaa esimerkiksi sitä, että ohjattavalle ei jää tilaa ajatella ja testata omia näkemyksiään tai hänelle annetaan valmiina tiettyjä ajatuksia ja näkökulmia.(Poutiainen \& Gerlander 2005.) Saarnivaara (2003) toteaa, että liiallinen huomioiminen johtaa haitalliseen riippuvaisuuteen, mikä puolestaan estää oppijan valtautumista (empowerment). Myös Heikkilä ja 
Heikkilä $(2001,26)$ näkevät, että valtautuminen ja itseohjautuvuus edellyttävät tiettyä vapauden tunnetta ja uskallusta uhmata ulkopuolelta tulevia rajoituksia ja määräyksiä. Ohjaajan tulisi osata pysytellä sopivan kaukana, jotta ohjattava voisi kehittää autonomisuuttaan. Toisaalta myös liian vähäinen ohjaus, liiallinen vapaus voi johtaa haitalliseen rilppuvaisuuteen, koska myöskään sïnä oppijan autonomisuus ei pääse kehittymään. (Saarnivaara 2003, 110.)

Opettajan näkökulmasta katsottuna tässä jännitteessä on kysymys esimerkiksi siitä, missä märin opettaja antaa opetuksessaan tilaa oppijoille. Missä asioissa ja millä tavoin opettaja esimerkiksi ottaa heidät mukaan oppimistavoitteista, -tehtävistä ja opetusmenetelmistä koskevaan päätöksentekoon? Opetuksen kehittämisessä korostetaan yhteistoiminnallisempaa, oppijalähtöisempää ja vuorovaikutuksellisempaa opetusta. Kun oppijat saavat enemmän mahdollisuuksia osallistua ja vaikuttaa opetukseen, samalla opettajan täytyy aina uudelleen asettaa oma tietämisensä ja asemansa kunkin oppijaryhmän kanssa neuvoteltavaksi. Kun vuorovaikutusrakenteita muutetaan, johtaa se väistämättä myös opettajan ja oppijan välisten valtasuhteiden muuttumiseen (ks. Nummenmaa \& Lautamatti 2004, 118). Opettajan autonomisuuden vähenemistä voidaan perustella sillä, että se tukee oppijoiden kehittymistä itsenäisemmiksi oppijoiksi ja toimijoiksi. Kuitenkin opettaja joutuu kysymään, missä on hänen autonomisuutensa alue ja miten hän ylläpitää sitä.

Yhteistoiminnallisuuden ja vuorovaikutteisen opetuksen korostaminen nostaa vahvemmin esille autonomisuuden ja rijppuvaisuuden jännitteen sekä opettajien ja oppijoiden kokemuksissa ja käsityksissä että heidän välisessä vuorovaikutuksessaan. On todennäköistä, että opettajan auktoriteetti on entistä vahvemmin vuorovaikutussuhteessa yhä uudestaan neuvoteltava ilmiö. Opettajan ja oppijan välillä neuvotellaan ja keskustellaan esimerkiksi siitä, missä määrin opettajan tehtävänä on tietää ja sanoa oikea vastaus ja missä määrin vastuu esimerkiksi ryhmäntyöskentelyn tuloksista on oppijoilla itsellään.

Välittämisen ja instrumentaalisuuden välisessä jännitteessä on kyse siitä, miten paljon tai missä määrin opettaja voi välittää oppilaistaan (Rawlins 2000). Jännite kuvastaa sitä, miten paljon välittäminen on itsessään tavoite ja missä määrin keino saavuttaa pedagogisia tavoitteita. Välittämisen ja instrumentaalisuuden jännitteen keskeisyys opettaja-oppijasuhteessa saa tukea myös Baumanin (1997) näkemyksessä sosiaalisista suhteista. Hänen mukaansa kaikki sosiaaliset suhteet sijoittuvat kahden päämotiivin - rakkaus/välittäminen ja raha/vaihto - väliselle jatkumolle. Tällä ulottuvuudella opettaja-oppijasuhde sijoittuu muiden interpersonaalisten asiantuntija-asiakassuhteiden tavoin jatkumon keskialueille. Bridge ja Baxter (1992) puhuvatkin yhdistelmäsuhteista, joille on luonteenomaista, että niihin kietoutuvat sekä välittämiseen pohjautuvien henkilökohtaisten suhteiden että vaihtoon pohjaavien instrumentaalis-strategisten suhtei- 
den ainekset. Molempien motiivien, välittämisen ja vaihdon, kietoutuminen toisiinsa tuottaa opettaja-oppijasuhteeseen jännitteisyyttä. Se, mihin kohtaan kahden päämotiivin välille kukin yksittäinen opettaja-oppijasuhde kulloinkin asettuu, riippuu osapuolten vuorovaikutussuhteessa syntyvistä tulkinnoista ja toiminnasta. Sen perusteella, mitä elementtejä opettaja-oppijasuhteessa kulloinkin korostetaan, voidaan lähentyä henkilökohtaista suhdetta, jossa korostuvat tuttavuus- ja ystävyyssuhteen elementit. Toisaalta se voi toteutua valmentajamaisena tai mentorisuhteena tai se voidaan nähdä perinteisen esimies-alaissuhteen kaltaisena.

Välittämisen ja instrumentaalisuuden jännite on keskeinen erityisesti ohjaussuhteissa tai koko lukukauden tai lukuvuoden kestävillä opintojaksoilla, joissa opettaja oppii tuntemaan oppilaansa henkilökohtaisesti ja tapaa heitä toistuvasti. Niissä opettajan ja oppijoiden vuorovaikutussuhteeseen voi tulla läheisyyttä rakentavia elementtejä jopa siinä määrin, että vuorovaikutussuhteissa on ystävyyssuhteen kaltaisuutta. Tällöin ongelmallista voi olla juuri se, että osapuolten odotukset ja tulkinnat henkilökohtaisuuden asteesta ovat erilaiset. Usein saattaa jäädä avaamatta, millaista henkilökohtaisuutta ja miten kokonaisvaltaista sitoutumista ja huomioonottamista ohjattavat ohjaajalta odottavat. Onko henkilökohtaisuuden ydin esimerkiksi siinä, että välittämisen osoittamisena puhutaan muutakin kuin ns. asiaa? Miten paljon ohjaajalta odotetaan esimerkiksi emotionaalista välittämisen osoittamista, mikä osaltaan lisää opetustyön emotionaalista taakkaa? 'Tarkoittaako välittäminen ensisijaisesti sitä, että ohjaaja ei hyväksy opiskelijan huonoa työtä ja ottaa opiskelijan näkökulman ja menestymisen vakavasti?

Poutiaisen ja Gerlanderin (2005) kuvaama asiakeskeisyyden ja henkilölkohtaisuuden välinen jännite on hyvin samansisältöinen instrumentaalisuuden ja välittämisen jännitteen kanssa. Heidän tutkimuksessaan tuli esille sekä ohjat-tavien että ohjaajien pyrkimys asiakeskeisyyteen: tietoa esimerkiksi elämäntilanteesta ei itse kerrottu, eikä odotettu toisenkaan kertovan, ellei sillä ollut merkitystä asian kannalta. Näyttääkin siltä, että välittäminen ohjaussuhteessa tarkoittaa ja se ilmaistaan osoittamalla kiinnostusta ja arvostusta ohjattavan tutkimusta ja sen etenemistä kohtaan. (Poutiainen \& Gerlander 2005.) Asiakeskeisyyden ja henkilökohtaisuuden jännite on ymmärrettävissä myös tyypillisenä suomalaisen opetuskontekstin viestintäkulttuuria luonnehtivana piirteenä. Wilkins $(2000,7)$ toteaa, että asiapuhe viestintätyyppinä määrittelee keskeisesti ihmisten välisiä suhteita suomalaisissa opetus- ja hoitokonteksteissa.

Opettajan tehtävän yhteydessä puhutaan usein siitä, voiko opettajan ja oppijan välille syntyä ns. aitoja välittämiseen perustuvia suhteita, kuten ystävyyssuhteita (ks. Rawlins 2000). Onko niin, että opettaja ei käytännössä voikaan sitoutua ohjaussuhteeseen syvemmin, koska hänellä on yleensä useita 
ohjattavia tai opetettavia eli jääkö lopputulokseksi se, että "olisimme voineet olla ystäviä"? Kuvaako pedagogisen ystävyyden käsite juuri tätä mahdollista ystävyyttä? Esimerkiksi Buberin $(1965,101)$ kanta ystävyyden mahdollisuuteen on selkeä: jos opettaja-oppijasuhde muuttuu ystävyyssuhteeksi, samalla menetetään opettaja-oppilassuhde.

Voidaan ajatella, että opettajan rajallinen käytettävissä oleva aika ja muut resurssit tekevät sen, että ohjaus- tai opetussuhteeseen sisältyy - ja on sisällyttävä - aina instrumentaalisuuden ja välittämisen ulottuvuus. Jos opettaja välittää liikaa, tällöin opettajan tulisi tunnistaa välittämiseen ja siihen mahdollisesti liittyviin kielteisiin tunteisiin liittyvät vääristymät: opettaja voi pyrkiä kompensoimaan omaa välittämistään joko liian ankaralla tai kevyellä arvioinnilla.

Huomattavaa on, että opettajan ja oppijan välistä vuorovaikutussubdetta kuvattaessa korostetaan usein välittämistä ja suhteen henkilökohtaisuutta. Melko yleisiä ovat toteamukset, että "työtä tehdään koko persoonalla" tai "opettaja luo henkilökohtaisen suhteen oppijoihin". Tällöin voi unohtua, että opettaja tarvitsee vuorovaikutussuhteissaan myös etäisyyttä. On tilanteita (esim. emotionaaliset latautuneet ohjaustilanteet), jolloin opettajan tulisi osata objektivoida suhde ja tarkastella sitä ulkopuolisena arvioijana sekä suhtautua opettamiseen instrumentaalisemmin. Pahimmillaan liiallinen henkilökohtaistaminen voi osaltaan lisätä opetuksen psykologisoimista eli sitä, että luokkahuoneen tapahtumat selitetään persoonallisuuden piirteillä eikä vuorovaikutusprosessin ilmiöillä. Liiallisuuksiin vietynä tämä haittaa oman työn kehittämistä ja siinä jaksamista. (Tainio \& Harjunen 2005, 184.)

Välittämisen ja instrumentaalisuuden välinen jännite on nähtävissä myös Harjusen (2002) opettajan pedagogista auktoriteettia tarkastelevassa tutkimuksessa. Hän jäsentää Kansasen ja Meren $(1999,112,114)$ mallin mukaisesti opettaja-oppijasuhdetta pedagogisena ja didaktisena suhteena. Kun suhde nähdään pedagogisena, oppimistehtävä asettuu opettajan ja oppijan väliseen vuorovaikutussuhteeseen, jossa opettaja suuntaa ja ohjaa oppijan oppimista. Pedagoginen suhde on luonteeltaan dialoginen, ei välineellistävä eikä esineellistävä ja siihen sisältyvät myös tunteet (Harjunen 2002, 106). Didaktisessa suhteessa fokus on puolestaan oppijan suhteessa oppimistehtävään, jota opettaja ohjaa ja tukee. Onnistuessaan didaktinen suhde näkyy opiskeluna, oppimisena ja muina muutoksina. Didaktinen opettajan ja oppijan välinen suhde korostaa sisältöä ja opettajan eksperttiyttä. (Harjunen 2002, 110.)

Harjusen (2002) tapaan tarkastella opettaja-oppilassuhdetta sisältyy kaksi kïnnostavaa näkökulmaa. Ensinnäkin, opettaminen on emotionaalista ja vaatii tunnetyötä. Siihen sisältyy samalla välittämisen, mutta myös kontrolloivan auktoriteetin (tietynlainen etäisyys ja instrumentaalisuus) välinen jännite. Pelkkä opiskeluun liittyvien sääntöjen ja normien korostaminen ilman välittämistä voi tukahduttaa opiskelijoiden haastavat kysymykset ja ideat. Toisaalta pelkkä 
välittäminen ei riitä opiskelun ja oppimisen tukemiseksi. Opettajan on oltava tarpeeksi kontrolloiva (esim. työskentelyrauhan tukeminen) ja kontrolloitu (esim. tarkoituksenmukainen tunteiden esittämisen hallinta), jotta oppijoiden mahdollisuus oppia ei vaarannu. Harjunen nostaakin tavoitteeksi pedagogis-didaktisen auktoriteettisuhteen, jonka toteutuminen on kiinni opettajan halusta olla ihminen ja opettaja: eettinen, välittävä, vastuuntuntoinen, oikeudenmukainen ja tehtävänsä tiedostava. Tällainen suhde tarjoaa tarvittavan etäisyyden, arvostuksen ja peilin: teemme töitä yhdessä mutta emme kuitenkaan samassa asemassa, samanlaisina. (Harjunen 2002, 157, 461, 464.)

Toiseksi, pedagogis-didaktinen auktoriteetti rakentuu nimenomaan oppijan ja opettajan kontaktin sekä opettajan toiminnan kautta (Harjunen 2002, 463). Näin auktoriteetin perusta itsessään ei ole opettajan henkilökohtaisissa ominaisuuksissa, vaan opettajan ja oppijan/oppijoiden välisessä suhteessa (ks. Burbules 1995, 36). Auktoriteetti on siis suhdeilmiö. Käytännössä pedagoginen auktoriteettisuhde luodaan luokkatilanteen interaktiossa, jossa ovat mukana läsnäolo, luottamus, vastuu, arvostus ja kunnioitus. (Harjunen 2002, 8.)

Arvioinnin ja byuäksymisen välisen jännitteen tarkoituksenmukainen ymmärtäminen on opettaja-oppijan vuorovaikutussuhteen vaativimpia tehtäviä. Jännitteen ydin on sïnä, miten viestiä oppijalle samanaikaisesti hyväksymistä ihmisenä ja kehittyvänä asiantuntijana, mutta toisaalta pitää mielessä opettajan velvollisuus huolehtia opetuksen laadusta ja arvioida oppijan töitä, suorituksia ja kehittymistä.

Usein opettaja pyrkii vuorovaikutussuhteessa välittömyyteen (verbaalista ja nonverbaalista toimintaa, jolla viestitään läheisyyttä) (ks. esim. McCroskey \& Richmond 1992) ja haluaa osoittaa hyväntahtoisuutta ja hyväksyntää oppijoita kohtaan.

Opettamisessa hyväksymistä voidaan Rawlinsin (2000) mukaan osoittaa myös sillä, että oppijoiden työ otetaan vakavasti ja että heiltä myös odotetaan parasta. Näin hyväksymisessä ei ole pelkästään kyse emotionaalisesta tai affektiivisesta suhtautumisesta toiseen. Esimerkiksi ohjaussuhteessa ohjaajan vastuu ohjata työtä toimivaan suuntaan voidaan ymmärtää juuri välittämisenä. Tämä velvollisuus voi johtaa siihen, että vuorovaikutustilanteessa opettaja voi kokea, että hän joutuu sanomaan hyvinkin tiukasti ohjattavalle, jotta viesti tulisi ymmärretyksi. Toisaalta työn tekijä voi kokea saamansa palautteen ankarana arvosteluna. Ohjattavat kuitenkin odottavat ohjaajalta arviointia ja kritiikkiä. Esimerkiksi Poutiaisen ja Gerlanderin (2005) tutkimuksessa jatkotutkinto-ohjattavat pitivät ohjaajaa "rimana" eli työn laadun takaajana.

Tämä puolestaan nostaa keskeisenä vaatimuksena esille ohjauksen ja palautteen rehellisyyden. Opettajan täytyisi pystyä vuorovaikutussuhteessa esimerkiksi antamaan rehellistä ja arvioivaa palautetta, mutta samalla hänen tulisi 
viestiä oppijan hyväksymistä henkilönä. Saarnivaara (2003) näkee, että ohjaajan rooli on olla samanaikaisesti suhteessa ja sen ulkopuolella, luoda henkilökohtainen yhteys mutta samalla myös toimia suhteen ulkopuolella pystyäkseen arvioimaan työskentelyä ja työtä.

Relationaalisen näkökulman mukaisesti oppijan työstä tai oppimisesta käytävä keskustelu tai niitä koskevat kommentit eivät koskaan liity pelkästään esimerkiksi oppijan kehittymiseen, vaan ne määrittävät ja rakentavat myös osapuolten välistä suhdetta. Ohjaussuhteita ajatellen työn tekijällä on usein hyvin emotionaalinen suhde omaan aiheeseensa, jolloin työtä koskevat kommentit ja arvioinnit tulevat herkästi ymmärretyiksi henkilökohtaisina ja koetaan kohdistuvan työn tekijään. Näin ollen varsinkin ohjaussuhteissa erityisen tärkeää on ohjaajan hienotunteisuus, mikä edellyttää ohjaajalta toimivia vuorovaikutussuhteen rakentamisen ja ylläpitämisen taitoja. Kun oppija pystyy luottamaan palautteen rehellisyyteen, vaikka palaute olisikin tiukkaa, parhaimmillaan hän voi samalla kokea itsensä hyväksytyksi.

Ilmaisemisen ja suojaamisen väliseen jännitteeseen kytkeytyvät kertomiseen ja kertomatta jättämisen teemat. Opettaja joutuu vuorovaikutussuhteessaan miettimään, mitä hän ilmaisee suoraan ja mitä hän on kertomatta tai ottamatta esille oppijan kunnioittamisen ja suojaamisen vuoksi. Joskus on syytä punnita, milloin kertominen esimerkiksi saattaa oppijan tuntemaan itsensä uhatuksi, haavoittaa oppijaa ja vaikuttaa hänen tunteisiinsa, itsetuntoonsa tai tilanteen ilmapiiriin. (Rawlins 2000, 13-14.) Yksittäisen oppijan lisäksi opettaja voi loukata myös koko oppijaryhmää. Kertomisen ja suojaamisen jännitteen rakentavan käsittelyn kannalta on olennaista, miten opettaja esimerkiksi luokka- tai luentoopetuksessa onnistuu rakentamaan luottamusta ja edelleen yhteisiä pelisääntöjä ja sopimuksia sen suhteen, mitä ja miten oppijat voivat sanoa missäkin tilanteessa ja millaista viestimistä on vältettävä.

Lisäksi olennaista tässä jännitteessä on kertomisen ja kertomatta jättämisen ajoitus. Esimerkiksi ohjaus- tai palautetilanteissa opettajan on ratkaistava, mitä asioita hän kussakin oppimisprosessinvaiheessa nostaa esille. Liian monien asioiden esille nostaminen voi latistaa oppijan opiskeluintoa ja haavoittaa hänen itsetuntoaan, erityisesti jos omasta työstä tai kehittymisestä keskustellaan muiden ryhmäläisten kuullen. Samoin kun oppijat antavat toisilleen palautetta: ymmärtävätkö he keskittyä oppimisen kannalta olennaisiin asioihin. Palautetta vastaanottaessaan oppija puolestaan joutuu asemoimaan itsensä suhteessa palautteeseen: missä määrin lähteä vuorovaikutukseen mukaan niin, että on riittävän avoin mutta toisaalta miten suojata itseään liialta henkilökohtaisesti ottamiselta. Onnistunut palautteen antaminen ja vastaanottaminen edellyttääkin oppijoilta ja opettajalta vuorovaikutustaitoja, eikä vähiten eettistä osaamista.

Kertomisen ja suojaamisen jännitteessä on myös kysymys siitä, miten opettaja ja oppija tulevat vuorovaikutuksessa esille yksityisinä ihmisinä, muuna kuin 
opettajana ja oppijana, tai siitä, että heitä kutsutaan tulemaan esille sellaisina. Kertomisen ja suojaamisen jännite liittyy siten sekä oppijan että opettajan yksityisyyden säilyttämiseen ja sen säätelyyn. Siihen sisältyy esimerkiksi kysymys oppijan oikeudesta päättää, mitä ja milloin hän kertoo itseään koskevista asioista. Henkilökohtaisten asioiden kertomiseen sisältyy aina riski, koska se paljastaa jotakin kertojan haavoittuvuudesta ja asettaa hänet alttiiksi arvostelulle. Oppija voi esimerkiksi miettiä, mitä hänen odotetaan kertovan HOPS-keskusteluissa. Miten paljon hän kertoo siitä, miten suunnitelmallisesti hän opiskelee tai millaisia työskentelytapoja ja -tottumulksia hänellä on? Entä mitä hän kertoo elämäntilanteestaan tai terveydentilastaan (esim. mielenterveysongelmistaan) selittäessään tai perustellessaan esimerkiksi opiskelunsa etenemistä? Opettaja puolestaan voi tuntea itsensä epävarmaksi, jopa ahdistuneeksi, jos oppijan itsestään antama tieto on liian henkilökohtaista. Opettaja joutuu miettimään, mitä hän kuulemallaan tiedolla tekee ja miten se vaikuttaa vuorovaikutussuhteeseen. Tulisiko hänen aktiivisemmin suojata oppijan yksityisyyttä ja ilmaista selkeästi, millaista tietoa keskustelussa odotetaan ja millainen ei puolestaan siihen kuulu?

\section{RELATIONAALISEN DIALEKTIIKAN NÄKEMYS DIALOGISTA}

Opettajan ja oppijan vuorovaikutussuhteen tavoitteeksi asetetaan usein dialogi tai dialogisen suhteen luominen (ks. esim. Burbules 1995). Tässä yhteydessä on muistettava, että dialogi-käsitettä käytetään hyvin monimerkityksisesti, eikä ole olemassa tarkkaa määritelmää siitä, millainen viestintämuoto tai -tyyppi dialogi on. Laajasti ymmärrettynä sillä voidaan tarkoittaa keskustelemista yleensä. Kuitenkaan mikä tahansa keskustelu oppijan ja opettajan välillä ei ole vielä dialogia. Esimerkiksi dialogia opetuksessa tarkastellut Burbules (1993, xii) toteaa, että dialogi ei ole jotakin mitä tehdään, vaan se on paljon vaikeampaa kuin tavallinen keskustelu. Dialogin olennainen piirre on siis muussa kuin yksittäisissä viestintäteoissa, vaikka yksittäisillä teoilla voidaan tukea dialogin syntymistä. Sekä Burbules (1993) että Buber (1965) ymmärtävät dialogin tietynlaisena subteen laatuna, jossa olennaista on suhtautuminen toiseen. Myös Cissna ja Anderson $(1998,64)$ näkevät dialogin suhteessa toiseen: he pitävät sitä ajattelutapana, kuten orientoitumisena toiseen ihmiscen. Dialogissa osallistujat yhteistyössä tavoittelevat tietoa, hyväksymistä tai interpersonaalista ymmärtämistä. Näin ollen dialogi on ennen kaikkea subde, johon tullaan ja jossa korostuvat yliyksilölliset piirteet. Dialogisen suhteen periaatteiksi Burbules $(1995,21)$ mainitsee a) kognitiivisen pyrkimyksen tavoitella tietoja ja ymmärrystä tai yhteistä näkemystä, b) affektiivisen välittämisen ja sitoutumisen sekä c) dialogin kyvyn "imaista" osallistujat mukaansa ja ylittää yksilölliset intentiot. Dialogi nähdään tällöin tavoiteltavana ja positiivisena ilmiönä. 
Dialogiin liitetään kriittisyys, arviointi ja yhteinen uuden tiedon luominen. Esimerkiksi Freire $(1990,81)$ toteaa, että vain kriittistä ajattelua vaativa dialogi voi tuottaa kriittistä ajattelua, mikä puolestaan on todellisen kasvatuksen (education) edellytys. Dialogissa ei myöskään ole kysymys jo olemassa olevan tiedon yhteiseksi tekemisestä, mikä typistäisi dialogin viestin välittämiseksi (Stewart, Zediker \& Black 2004, 34-35), vaan siinä on kysymys nimenomaan uuden tiedon ja tietämisen yhteisestä luomisesta (Bohm 1996, 2).

Relationaalisen dialektiikan näkökulmasta dialogin olennainen piirre on jännitteisyys (Baxter 2004; Stewart \& Zediker 2000). Kärjistetysti ilmaistuna dialogi ei tarkoita ensisijaisesti tyytyväistä myöntyväisyyttä tai lämminhenkistä keskustelua (Anderson 2003, 81), vaan siinä on kysymys syvästä ja erityisestä toisen ja hänen erilaisuutensa kohtaamisesta. Clark ja Holquist $(1984,9)$ toteavat, että dialogille on ominaista samanaikainen erilaisuus - "communication between simultaneous differences". Itse asiassa jännitteisyyden lähtökohta sisältyy jo itse viestintään: vaikka viestintä on yhteisten merkitysten luomista ja yhteisyyden rakentamista, se perustuu myös jaotteluihin ja vastakohtiin (ks. Anderson 2003). Dialogia voidaan kuvata useiden jännitteiden kautta. Siihen sisältyy muun muassa erilaisuuden ja samanlaisuuden, yhteyden ja erillisyyden, kertomisen ja suojaamisen, yllätyksellisyyden ja ennustettavuuden sekä monologisuuden ja dialogisuuden väliset jännitteet.

Dialogin ymmärtäminen jännitteisenä tarkoittaa, että dialogi ei voi olla pysyvä tila, vaan dynaaminen ilmiö, jolle on ominaista hetkellisyys (ks. Bahtin 1981; Baxter 2004; Buber 1957; Rogers 1987). Esimerkiksi Buberille (1957) dialogi syntyy kohtaamisessa, jossa keskinäisyys (mutuality) toteutuu ja Bahtin (1990, 67) näkee dialogin ohikiitävänä hetkenä, jolloin jännitteet ja epäjärjestys hetkellisesti yhdistyvät kokonaisuudeksi. Jännitteet eivät "ratkea" tai häviä, vaan ne ikään kuin hetkeksi niputtuvat yhteen.

Kun dialogia tarkastellaan relationaalisen dialektiikan näkökulmasta, sitä ei aseteta vuorovaikutuksessa kyseenalaistamattomaksi vuorovaikutuksen ihanteeksi ja päämääräksi. Monologinen ja dialoginen suhde ovat neutraaleja suhteessa toisiinsa. Kumpaakaan ei pidetä kielteisinä tai myönteisinä itsessään, vaan ne molemmat nähdään olennaisesti toimintaan kuuluvina, sen kannalta tarpeellisina. Osallistujan, kuten opettajan ja oppijan kannalta dialogi merkitsee sitä, että siihen kuuluu myös vetäytyminen, etäisyyden ottaminen itseen ja toisiin. Voidaankin kysyä, onko joskus tarpeellista jopa pyrkiä vuorovaikutussuhteessa kohteellistamaan toinen eli monologiseen suhteeseen, eikä tavoitella dialogia esimerkiksi siksi, että monologinen suhde turvaa ensisijaisten tehtävien suorittamisen tai tavoitteiden saavuttamisen. Tällaisia ovat esimerkiksi emotionaalisesti stressaavat tilanteet, joissa toisen tilanteen syvä kohtaaminen voisi heikentäisi tehtävän suorittamista. Hoitotyötä pohtineet Keskinen ym. (1997, 155) toteavat: 


\section{"Hoitotyön koulutuksessa korostetaan boitajan ja potilaan välistä subjekti-subjektti}

-subdetta. Potilaan ammattitaitoiseen boitamiseen voi kuitenkin liittyä tilanteita, jolloin potilaan kobteellistaminen on välttämätöntä. Tämä on etäisyyden ottamista potilaaseen, jotta boitaja voi toimia tavoitteiden mukaisesti."

Samaa voidaan pohtia myös opetustyössä: onko aidon dialogin tavoitteleminen joskus haitallista opettajan ja oppijan vuorovaikutussuhteen ja oppimisen kannalta? Esimerkiksi ohjaussuhteessa voi olla emotionaalisesti latautuneita tilanteita, jolloin molemminpuolisen dialogiin pyrkimisen sijasta voi olla parempi ottaa tietoista etäisyyttä oppijaan tai oppijaryhmään.

Relationaalisen dialektiikan näkökulma haastaa opettajaa miettimään käsitystään dialogista, mitä hän sillä kulloinkin opetuksessa tavoittelee, mitä haasteita hän näkee siihen sisältyvän ja miten hän ymmärtää siihen liittyvän vastuun. Tunnistaako opettaja esimerkiksi omat rajansa lähteä dialogiseen suhteeseen? Jos opettaja ei ole miettinyt, mihin hän on sitoutumassa, onko silloin kyseessä enää ammatillinen toiminta? Lisäksi, jos dialogin jännitteisyys ja vaativuus otetaan lähtökohdaksi, olennaisia kysymyksiä ovat myös oppijoiden odotukset dialogiselle opetukselle sekä heidän valmiutensa ja halunsa osallistua siihen. Osa oppijoista saattaa ymmärtää dialogin siten, että asioista "vain keskustellaan", tai jotkut odottavat, että “milloin mennään varsinaiseen asiaan". Miten oppijat ymmärtävät dialogiseen suhteeseen sisältyvän vastuun?

Dialogiin osallistuminen ja toisten erilaisuuden kohtaaminen on viestinnällisesti vaativaa. Dialogi voi herättää hankalina koettuja tunteita, joiden esittämistä ei pystytä hallitsemaan tai joiden vastaanottaminen koetaan ahdistavana. Lisäksi dialogi edellyttää jokaisen läsnäolijan aitoa osallistumista, vastuuta omasta osallistumisesta ja vastuuta vastata toisille (ks. Värri 1997). Oppijan tulisi avata omaa ajatteluaan ja siten myös itseään toisille ja toisten arvioinnille. Anderson $(2003,81)$ toteaakin, että dialogi paljastaa ihmisistä paljon ja haastaa meitä uudelleen ajattelemaan, keitä me olemme. Se vaatii meitä olemaan riittävän avoimia muita dialogiin osallistujia kohtaan, mutta samalla se edellyttää, että meillä on rïttävän vankka pohja oman osallistumisemme suhteen (Anderson 2003, 81; ks. myös Värri 1997).

Relationaalisen dialektiikan näkökulmaa dialogiin voidaan pitää realistisena, sillä se nostaa esille myös dialogiin sisältyvät ristiriitaiset ja vastakkaiset piirteet. Dialogiin pyrkimisen merkitys tunnustetaan, mutta dialogia ei ajatella yksioikoisena ideaalina päämääränä, jossa koetaan pelkästään yhteisyyttä sekä luodaan uutta ymmärrystä. Se nähdään hetkellisenä vuorovaikutussuhteena, joihin sisältyy välittämisen, yhteisyyden ja ymmärryksen lisälssi myös haavoittuvuutta, epävarmuutta, epämiellyttävyyttä ja näin ollen myös tarvetta vetäytyä, suojata itseä ja toisia. 


\section{\ Aiheita jatkotutkimukselle}

Tutkittaessa relationaalisia jännitteitä olisi tärkeää tarkastella sekä oppijoiden ja opettajien kokemuksia suhteesta ja siinä toimimisesta että heidän välistä autenttista vuorovaikutusta. Opettajan ja oppijan vuorovaikutussuhteen tarkasteleminen relationaalisten jännitteiden kautta nostaa esille ilmiöitä, jotka tekevät ymmärrettävämmäksi sekä opettajan ja oppijan väliseen vuorovaikutussuhteeseen sisältyviä haasteita ja ristiriitaisuuksia että opettajan ja oppijan vuorovaikutuskokemuksia. Yhtenä relationaalisen dialektiikan vahvuutena pidetäänkin sitä, että se kuvastaa suhteen osapuolten kokemuksia suhteesta ja siinä toimimisesta.

Jännitteisyyden ymmärtäminen korostuu esimerkiksi tilanteissa, joissa opettaja antaa palautetta oppijalle ja arvioi hänen oppimistaan tai oppijat antavat palautetta toisilleen. Niissä ei ole kyse vain oppimistehtävän suorittamista koskevan tiedon antamisesta, vaan samalla luodaan tietynlainen suhde toiseen ja määritetään toista osapuolta suhteessa itseen. Miten samanaikaisesti toisaalta osoittaa oppijan kunnioittamista ja hyväksyntää (suojata hänen kasvojaan), mutta toisaalta tuoda esille oppijan tuotokseen tai näkemykseen sisältyvä ongelmallisuus tai virheellisyys? Tutkimusta tarvittaisiin esimerkiksi siitä, miten hyväksymisen ja arvioinnin välinen jännite toteutuu opetusvuorovaikutuksessa ja millaisilla tavoilla sitä pyritään käsittelemään.

Relationaalisia jännitteitä voidaan lähestyä myös siitä näkökulmasta, millaisia odotuksia opettajan ja oppijan vuorovaikutussuhteeseen sisältyy erilaisissa opetusmuodoissa (esimerkiksi luento, ohjaus, pienryhmäopetus, dialogiopetus). Mikä nähdään opettajan ja oppijan oikeuksina, velvollisuuksina tai vastuuna (esim. vuorovaikutusvastuuna)? Entä mitkä relationaaliset jännittect ovat keskeisimpiä eri opetusmuodoissa? On oletettavaa, että ohjaussuhteessa korostuvat autonomisuutta ja riippuvaisuutta sekä arvioimista ja hyväksymistä ilmentävät jännitteet. Entä mitkä jännitteet ovat keskeisiä luento-opetuksessa tai pienryhmätyöskentelyssä?

Jännitteitä tulisi tarkastella myös jatkuvuuden näkökulmasta. Onko esimerkiksi ohjaussuhteessa olemassa tiettyihin vaiheisiin liittyviä kriittisiä kohtia, joissa tulisi olla tietoinen suhteen jännitteistä ja pyrkiä käsittelemään niitä tietoisesti? Milloin esimerkiksi oppimisprosessin etenemisen kannalta on tärkeää, että oppija tuo esille omaa autonomisuuttaan tai milloin opettajan tulisi erityisesti pitää esillä oppijan autonomisuutta? Entä milloin opettaja joutuu oppimisen nimissä rajoittamaan oppijan autonomisuutta ja osoittamaan hänen riippuvaisuuttaan toisista oppijoista tai itsestään?

\section{KIRJALLISUUS}

Almeida, E. P. 2004. Discourse analysis of student perceptions of their communication competence. Communication Education 53, 357-365. 
Anderson, R. 2003. Literature and the particularities of dialogue. Quarterly Journal of Speech 89 (1), 78-82.

Bahtin, M. 1981. The dialogic imagination: four essays by M. M. Bakhtin. Toimittanut M. Holquist. Kääntäneet C. Emerson \& M. Holquist. Austin: University of Texas Press.

Bauman, Z. 1997. Sosiologinen ajattelu. Suom. J. Vainonen. Tampere: Vastapaino. (Alkuperäisteos 1990.)

Baxter, L. A. 2004. Relationships as dialogues. Personal Relationships 11, 1-22.

Baxter, L. A. \& Montgomery, B. M. 1996. Relating. Dialogues \& Dialectics. New York: The Guilford Press.

Bohm, D. 1996. On dialogue. London: Routledge.

Booth-Butterfield, M. 1992. Influence and control in the classroom. Edina: Burgess International Group.

Bridge, K. \& Baxter, L. A. 1992. Blended friendships: friends as work associated. Western Journal of Communication 56, 200-225.

Bruschke, J. \& Gartner, C. 1991. Teaching as communicating: advice for the higher education classroom. Journal of Applied Communication Research 19, 197-216.

Buber, M. 1957. Pointing the way: collected essays. New York: Harper \& Row.

Buber, M. 1965. Between man and man. New York: Collier Books.

Burbules, N. C. 1993. Dialogue in teaching. Theory and practice. New York: Teachers College Press.

Burbules, N. C. 1995. Authority and the tragic dimension of teaching. Teoksessa J. W. Garrison \& A. G. Jr. Rud (toim.) The educational conversation, Closing the gap. Albany: State University of New York Press, 29-40.

Burk, J. 2001. Communication apprehension among Master's of Business administration students: investigating a gap in communication education. Communication Education 50, 51-58.

Cissna, K. N. \& Anderson, R. 1998. Theorizing about dialogic moments: The Buber - Rogers position and postmodern themes. Communication Theory 8, 63-104.

Clark, K. \& Holquist, M. 1984. Mikhail Bakhtin. Cambridge: The Belknap Press of Harvard University Press.

Deetz, S. A. 1994. Future of the discipline: the challenges, the research, and the social contribution. Teoksessa S. A. Deetz (toim.) Communication Yearbook 17. Thousand Oaks: Sage, 565-600.

Feezel, J. D. 1987. The communication skills of teachers: a coherent conception. Teoksessa J. L. McCaleb (toim.) How do teachers communicate? A review and critique of Assessment practices. Washington: Clearinghouse on teacher education, 29-42.

Freire, P. 1990. Pedagogy of the oppressed. Kääntänyt M. B. Ramos. New York: Continuum.

Frymier, A. B. \& Houser, M. L. 2000. The Teacher-Student Relationship as an Inter- 
personal Relationship. Communication Education 49 (3), 207-219.

Gerlander, M. 2003. Jännitteet lääkärin ja potilaan välisessä viestintäsuhteessa. Jyväskylän yliopisto. Jyväskylä Studies in Humanities 3.

Griffin, E. 2003. A first look at communication theory. $5^{\text {th }}$ ed. Boston: McGraw.

Harjunen, E. 2002. Miten opettaja rakentaa pedagogisen auktoriteetin? Otteita opettajan arjesta. Suomen kasvatustieteellinen seura. Kasvatusalan tutkimuksia 10.

Heikkilä, J. \& Heikkilä, K. 2001. Dialogi - Avain innovatiivisuuteen. Helsinki: WSOY.

Kansanen, P. 1999. Teaching as teaching-studying-learning interaction. Scandinavian Journal of Educational Research 43 (1), 81-89.

Kansanen, P. \& Meri, M. 1999. The didactic relation in the teaching-studying-learning process. TNTEE Publications 2 (1), 107-116.

Keskinen, T., Koskela, P., Lehto, R., Manninen, H. \& Tiainen, E. 1997. Kehollinen dialogi. Teoksessa R.-L. Heikkinen \& T. Laine (toim.) Hoitava kohtaaminen. Helsinki: Kirjayhtymä, 146-153.

Kumpulainen, K. \& Wray, D. 2004. Classroom interaction and social learning. From theory to practice. London: Routledge.

Leeds-Hurwitz, W. (toim.) 1995. Social approaches to communication. New York: Guilford.

Martin, M. M., Myers, S. A. \& Mottet, T. P. 1999. Students' motives for communicating with their instructors. Communication Education 48, 155-164.

McCaleb, J. L. (toim.) 1987. How do teachers communicate? A review and critigue of assessment practices. Washington: Clearinghouse on teacher education.

McCroskey, J. C. \& Richmond, V. P. 1992. Increasing teacher influence through immediacy. Teoksessa V. P. Richmond \& J. C. McCroskey (toim.) Power in the classroom: communication, control, and concern. Hillsdale: Lawrence Erlbaum, 101-120.

McCroskey, J. C., Sallinen, A., Frayer, J. M., Richmond, V. P. \& Barraclough, R. A. 1996. Nonverbal immediacy and cognitive learning: A cross-cultural investigation. Communication Education 45, 201-211.

McCroskey, L. L., Richmond, V. P. \& McCroskey, J. C. 2002. The scholarship of teaching and learning. Contributions from the discipline of communication. Communication Education 51 (4), 383-391.

Mifsud, M. L. \& Johnson, S. D. 2000. Dialogic, dialectic, and thetoric: Exploring human dialogue across the discipline. Southern Communication Journal 65, 91-104.

Nummenmaa, A. R. \& Lautamatti, L. 2004. Ohjaaja opinnäytetöiden työprosessissa. Ryhmäohjauksen käytäntöä ja teoriaa. Tampere: Tampere University Press.

Nussbaum, J. F. \& Friedrich, G. 2005. Instructional/developmental communication: current trends, research, and future trends. Journal of Communication 55, 578593.

Penman, R. 2000. Reconstructing communicating: Looking to a future. Mahwah: Lawrence Erlbaum.

Poutiainen, S. \& Gerlander, M. 2005. Cultural dialectics in the Finnish advising rela- 
tionship. Esitelmä ICA:n vuosikongressissa. New York 26.-30.5.2005.

Rasku-Puttonen, H. \& Rönkä, A. 2004. Opettajankoulutuksen tehtävä koulukulttuurin muutoksessa. Teoksessa L. Launonen \& L. Pulkkinen (toim.) Koulu kasvuyhteisönä. Jyväskylä: PS-kustannus, 175-185.

Rawlins, W. K. 1998. Making meaning with friends. Teoksessa R. L. Conville \& E. Rogers (toim.) The meaning of "relationship" in interpersonal communication. Westport: Praeger, 149-169.

Rawlins, W. K. 2000. Teaching as a mode of friendship. Communication Theory 10, 5-26.

Richmond, V. P. \& McCroskey, J. M. (toim.) 1992. Power in the classroom: communication, control and concern. New Jersey: Lawrence Erlbaum.

Rogers, C. R. 1987. Comments on the issue of equality in therapy. Journal of Humanistic Psychology 27, 38-40.

Saarnivaara, M. 2003. Pedagogisesta ohjaamisesta laatua oppimiseen? Teoksessa G. Knubb-Manninen (toim.) Laadun tekijät: havaintoja yliopisto-opetuksesta. Jyväskylän yliopisto. Koulutuksen tutkimuslaitos, 101-119.

Sallinen-Kuparinen, A. (toim.) 1987. Perspectives on instructional communication. Jyväskylän yliopisto. Viestintätieteiden laitoksen jullkaisuja 5.

Sallinen-Kuparinen, A. 1992. Teacher communicator style. Communication Education 41, 153-166.

Seppälä, R. 1995. Opettajien puheviestinnälliset valmiudet. Teoksessa M. Valo (toim.) Haasteita puheviestinnän opetukseen. Jyväskylän yliopisto. Viestintätieteiden laitoksen julkaisuja 14, 207-224.

Sigman, S. J. 1998. Relationships and communication. A social communication and strongly consequential view. Teoksessa R. L. Conville \& L. E. Rogers (toim.) 'The meaning of "relationship" in the interpersonal communication. Westport: Praeger, 47-68.

Staton, A. 1989. The interface of communication and instructional: conceptual considerations and programmatic manifestations. Communication Education 38, 364-371.

Stewart, J. \& Zediker, K. E. 2000. Dialogue as tensional ethical practice. Southern Communication Journal 65, 224-242.

Stewart, J., Zediker, K. E. \& Black, L. 2004. Relationships among philosophies of dialogue. Teoksessa R. Anderson, L. A. Baxter \& K. N. Cissna (toim.) Dialogue. Theorizing difference in communication studies. Thousand Oaks: Sage, 21-38.

Tainio, L. \& Harjunen, E. 2005. Pedagogisen auktoriteetin rakentuminen luokkahuoneen vuorovaikutuksessa. Opettajan näkemykset ja tuntikäytänteet kahden metodin valossa. Kasvatus 3, 172-186.

Tracy, K. 2000. Everyday talk. Building and reflecting identities. New York: The Guilford Press.

Trenholm, S. \& Jensen, A. 1992. Interpersonal Communication. $2^{\text {nd }}$ ed. Belmont: 
Wadsworth.

Vehviläinen, S. 2004. Tunteet ja vuorovaikutus. Aikuiskasvatus 2, 141-153.

Värri, V.-M. 1997. Hyvä kasvatus - kasvatus hyvään. Dialogisen kasvatuksen filosofinen tarkastelu erityisesti vanhemmuuden näkökulmasta. Tampere: Tampere University Press.

Watzlawick, P., Bavelas, J. B. \& Jackson, D. D. 1967. Pragmatics of human communication. New York: Norton.

Wilkins, R. 2000. Infocentrism: an interactional code in some Finnish educational scenes. Esitelmä "Rhetoric and Communication in the 21th Century" NCA:n kesäkongressissa. Jyväskylä 14.-16.6.2000.

Witt, P. L. \& Wheeless, L. R. 2001. An experimental study of teachers' verbal and nonverbal immediacy and students' affective and cognitive learning, Communication Education 50, 327-342. 